\title{
Malignant lymphoma presenting as fulminant hepatic failure
}

\author{
Elizabeth Nizalik, MD, Ekrem Zayed, MD, FRCPC, AnNette Foyle, MD, CM, FRCPC, FCAP
}

\begin{abstract}
A patient with fulminant hepatic failure who had a T8 malignant lymphona is described. A review of the literature yields 11 other cases with hematologic malignancies with similar presentation. To the authors' knowledge this is the first case in which cell marker analysis was performed. Pitfalls in morphologic diagnosis are discussed. Can J Gastroenterol 1989;3(3):111-114
\end{abstract}

Key Words: Fulminant hepatic failure, Immunoblastic, T8 lymphoma, Malignant lymphoma, Polymorphous

\section{Le lymphome malin et l'insuffisance hépatique fulminante}

RESUME: Le cas d'un patient atteint d'insuffisance hépatique fulminante et ayant un lymphome malin T8 est décrit. Une étude des publications portant sur le sujet révèle 11 autres cas de tumeurs malignes hématologiques se présentant de la même manière. D'après l'auteur, il s'agit du premier cas pour lequel une analyse utilisant les marqueurs cellulaires a été effectuée. Les pièges du diagnostic morphologique sont examinés.

Department of Pathology, Dalhousie University; and the Victoria General Hospital, Halifax,

Nova Scotia

Correspondence and reprints: Dr A. Foyle, Victoria General Hospital, Department of

Pathology, 1278 Tower Road, Halifax. Nova Scotia B3H 2Y9. Telephone (902) 428-3731

Received for publication November 15, 1988. Accepted February 27, 1989
L

IVER INVOLVEMENT DURING THE course of both Hodgkin's and nonHodgkin's lymphoma is not unusual (1) and jaundice may develop (2,3). However, fulminant hepatic failure is rarely a presenting feature of malignant lymphomas and, when it occurs, the clinical picture may strongly suggest virus, alcohol or drug induced hepatitis (4). A case whose presentation with malignant lymphoma was dominated by fulminant and fatal hepatic failure is described. A review of the literature yields 11 other cases with a similar presentation (6-11).

\section{CASE PRESENTATION}

A 66-year-old caucasian woman was hospitalized having presented with lethargy, anorexia and vomiting of several days duration. The patient also noted decreasing energy and a $2.5 \mathrm{~kg}$ weight loss over a period of one year since having a tooth abscess complicated by sep- 
ticemia. There were no other symptoms. The patient did not consume alcohol and there was no history of blood transfusions; hypertension was treated with a diuretic. Physical examination revealed fever $\left(38.8^{\circ} \mathrm{C}\right)$ and an erythematous pharynx with no exudate. The remainder of the examination was normal, including the abdominal examination.

Investigations revealed hemoglobin $145 \mathrm{~g} / \mathrm{L}$, white blood cell count $6600 / \mathrm{mm}^{3}$ and hyponatremia (sodium $127 \mathrm{mEq} / \mathrm{L}$ ). Despite supportive, steroid and ampicillin treatment, on day 6 the patient's abdomen became distended and tender with right upper quadrant pain and peripheral edema. This was accompanied by hyperbilirubinemia, hypoproteinemia and thrombocytopenia. On transfer to the authors' hospital on the next day, blood pressure was $110 / 80 \mathrm{mmHg}$, respiratory rate $24 / \mathrm{min}$, pulse 100 beats/ min and temperature $38.7^{\circ} \mathrm{C}$. The patient was lethargic and oriented to person only. There was dehydration, jaundice, anasarca, palmar erythema, asterixis and oral petechiae. The abdomen was obese but also distended and soft, and there was shifting dullness.

On day 7 of the illness (transfer day) the laboratory investigations were as follows: hemoglobin $107 \mathrm{~g} / \mathrm{L}$; platelets $1600 / \mathrm{mm}^{3}$; white blood cell count $6500 /$ $\mathrm{mm}^{3}$; neutrophils $4000 / \mathrm{mm}^{3}$; lymphocytes $2000 / \mathrm{mm}^{3}$; aspartate aminotransferase 195 (normal 8 to $29 \mathrm{iu} / \mathrm{L}$ ); alanine aminotransferase 132 (normal 1 to 41 $\mathrm{iu} / \mathrm{L}$ ); lactate dehydrogenase 2405 (normal 117 to $259 \mathrm{iu} / \mathrm{L}$ ); and alkaline phosphatase 402 (normal 30 to $104 \mathrm{iu} / \mathrm{L}$ ). Total bilirubin was 95 (normal 0 to 16 $\mu \mathrm{M} / \mathrm{L}$ ); albumin 23 (normal 38 to 50 $\mathrm{g} / \mathrm{L}$ ); ammonia 76 (normal 5 to $35 \mu \mathrm{M} / \mathrm{L}$ ); partial thromboplastin time 33.5 (normal 25 to $35 \mathrm{~s}$ ); and prothrombin time 13.5 (normal 10.5 to $12.5 \mathrm{~s}$ ).

The steroids were continued and the antibiotic was changed to ticarcillin and tobramycin. Platelet transfusions were given. The patient developed bilateral pleural effusions, metabolic acidosis and encephalopathy. Lactulose was started. Bone marrow aspirates were done on the eight and ninth days of illness. On the 10th day, the hemoglobin fell from 82 to $51 \mathrm{~g} / \mathrm{L}$ and blood transfusions were given. The patient suffered cardiac arrest

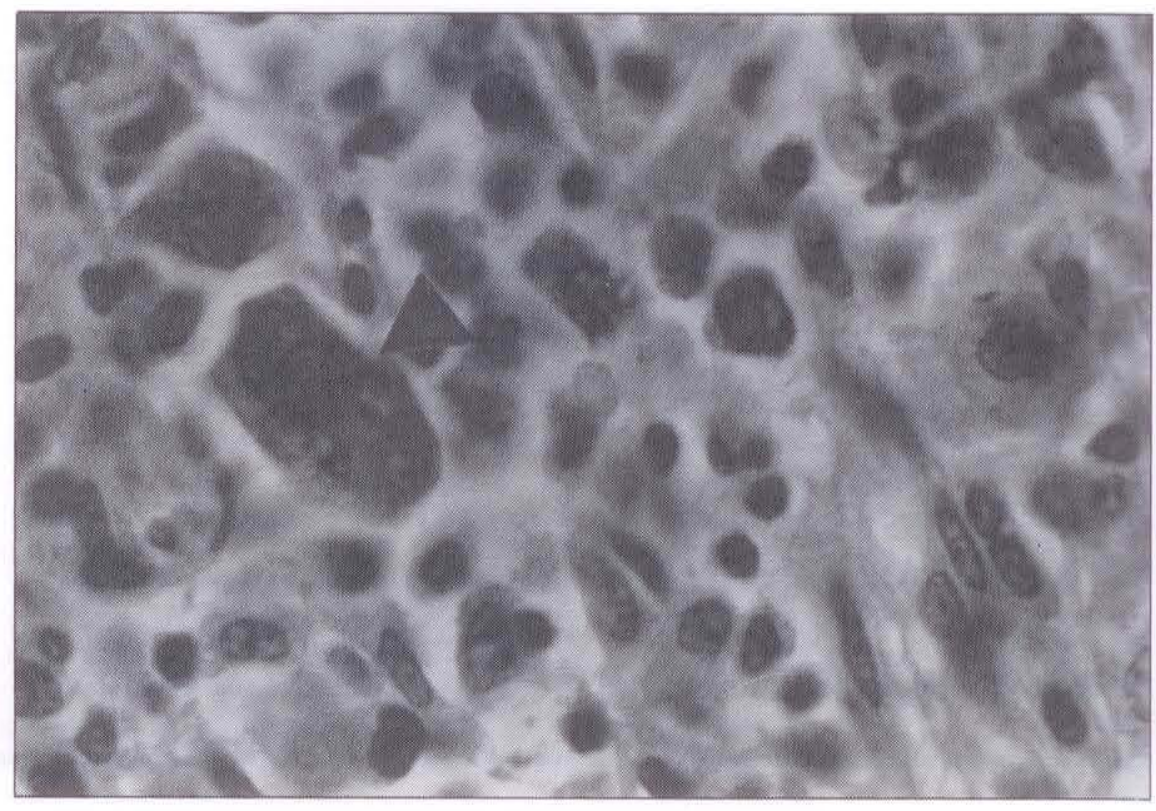

Figure 1) Lymph node showing polymorphous lymphoid infiltrate with a Reed-Sternberg-like cell (arrow); $(\times 5300)$

later that day and died. The clinical differential was viral hepatitis or a lymphoproliferative disorder. Serum was negative for hepatitis B surface antigen (HBsAg) and antibody to HBsAg. Serology for hepatitis A was not performed.

\section{BONE MARROW}

The first bone marrow aspirate showed some atypical lymphoid cells but this was not diagnostic and a second specimen was requested. The second bone marrow aspirate showed replacement of normal marrow with lymphoid cells with nuclei of varying size and shape with nucleoli and mitoses. Some similar small abnormal lymphoid cells were present in the peripheral blood and these increased in number terminally. Erythrophagocytosis was seen in benign histiocytes.

Cell surface marker analysis was performed on the cells obtained from the second bone marrow aspirate, using a method from Ortho Diagnostic Systems Inc (Raritan, New Jersey). Mouse monoclonal antibodies OKT3, OKT4, OKT8 and OK1al from Ortho Diagnostic Systems, and NKH1 from Coulter and B from Meloy were used.

The bone marrow was collected in heparin, centrifuged and the plasma was discarded. The cells were resuspended in phosphate buffered saline. Mononuclear cells were separated by Ficoll-Paque density solution and washed twice in phosphate buffered saline with $2 \%$ serum. The cells were resuspended in $1.0 \mathrm{~mL}$ phosphate buffered saline with $2 \%$ serum and the cell count was adjusted to $1 \times 10^{7} \mathrm{cell} \mathrm{s} / \mathrm{mL}$. The cells were incubated with the mouse monoclonal antibodies and Ortho FITC-conjugated goat antimouse $\mathrm{IgG}$ was added. The cells were counted with the fluorescent microscope. Terminal deoxynucleotidyl transferase was done by an immunoperoxidase technique from Supertechs Inc (Bethesda; Maryland). The following results were obtained: $82 \%$ of the bone marrow lymphoid cells were mature T lymphocytes expressing the $\mathrm{T} 3$ antigen; $76 \%$ were $\mathrm{T} 8$ cells; $5 \%$ were T4 cells; and terminal deoxynucleotidyl transferase was negative.

\section{AUTOPSY RESULTS}

The liver was cholestatic and weighed $1700 \mathrm{~g}$. There was no biliary obstruction and there was mild splenomegaly ( 250 g). The cystic duct, pancreatic and one para-aortic lymph nodes were enlarged ( $2.5 \mathrm{~cm}$ each).

Histology showed diffuse non-Hodgkin's lymphoma involving thoracic and abdominal lymph nodes, spleen and bone marrow, liver, myocardium, lungs, kidney and cervix. The infiltrate was pleomorphic, consisting of bizarre atypical lymphocytes. The nucleus varied in 
size and shape. Some nuclei were hyperchromatic and hyperlobated, while others were vesicular with prominent nucleoli. Some cells resembled ReedSternberg cells (Figure 1). There were widespread infiltrates in portal tracts and adjacent sinusoids with cholestasis (Figure 2). The remaining hepatocytes appeared normal. Candida albicans epiglottitis and esophagitis were also noted.

\section{DISCUSSION}

Fulminant hepatic failure is defined as a clinical syndrome of sudden onset resulting from severe impairment of liver function (5). There should be no preexisting liver disease. The most common cause is massive hepatic necrosis due to acute viral hepatitis $A$, hepatitis $B$ or non$A$, non- $B$ hepatitis. In this case, the syndrome should occur within eight weeks of onset of symptoms. Alcohol and drugs such as halothane, monoamine oxidase inhibitors, izoniazid and acetaminophen have also been reported to give rise to fulminant hepatic failure. Less commonly, fatty liver of pregnancy and surgical shock are responsible. Lymphoma is disfinctly an uncommon cause.

A review of the literature yielded 11 other patients with lymphoproliferative and malignant histiocytic disorders who presented in a similar fashion with fulminant hepatic failure (6-11) (Table 1). The patients, seven males and four females, ranged in age from 24 to 79 years. Death occurred within $48 \mathrm{~h}$ to

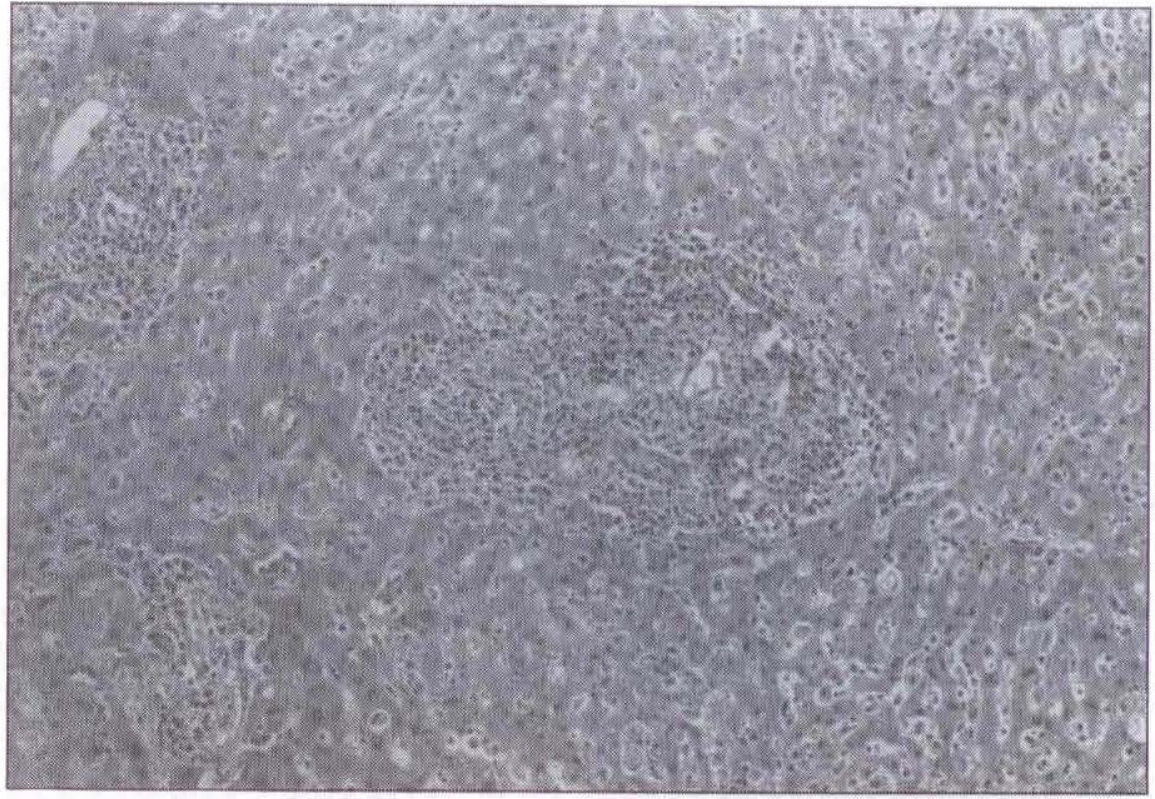

Figure 2) Liver showing an expanded portal tract in the centre with a spectrum of lymphoid cells also infiltrating sinusoids. $(\times 530)$

three months. In nine cases the liver failure was clinically attributed to acute infectious or drug induced hepatitis; only two cases were attributed to neoplastic disease. The diseases were Hodgkin's disease (five cases), non-Hodgkin's lymphoma (two cases) and malignant histiocytosis (three cases). One was designated only as primitive lymphoreticular malignancy but was suspected to be malignant histiocytosis. At autopsy, all except one patient showed tumour involvement of the liver. In most cases, involvement of the spleen and lymph node was noted. In the exception, the bile duct was obstructed by involved porta hepatic nodes.

The present case resembled some of the above cases morphologically. It is interesting to note that Colby and LaBrecque (6) describe a polymorphous infiltrate with bizarre hyperlobated nuclei and some erythrophagocytosis, particularly in view of the erythrophagocytosis the authors observed in benign histiocytes. To the authors' knowledge, the present case is the first such case in which the cell surface markers were considered.

\section{TABLE 1}

Other cases of malignant lyphoma presenting as fulminant hepatic failure

\begin{tabular}{|c|c|c|c|c|c|c|}
\hline Reference & Age (sex) & $\begin{array}{l}\text { Autopsy } \\
\text { diagnosis }\end{array}$ & $\begin{array}{l}\text { Premortem } \\
\text { diagnosed }\end{array}$ & HAV-IgM & $\mathrm{HBsAg}$ & $H B s A B$ \\
\hline Braude et al (7) & $24 \mathrm{M}$ & Non-Hodgkin's lymphoma & - & Negative & Negative & Negative \\
\hline Zafrani et al (11) & $66 \mathrm{~F}$ & Burkitt's lymphoma & Bone marrow & na & na & na \\
\hline Colby and LaBrecque (6) & $\begin{array}{l}30 \mathrm{~F} \\
30 \mathrm{M} \\
60 \mathrm{M} \\
65 \mathrm{M}\end{array}$ & $\begin{array}{l}\text { Malignant histiocytosis } \\
\text { Malignant histiocytosis } \\
\text { Malignant histiocytosis } \\
\text { Primitive Iymphoreticular } \\
\text { malignancy? Malignant } \\
\text { histiocytosis }\end{array}$ & $\begin{array}{c}- \\
\text { Bone marrow, liver } \\
- \\
-\end{array}$ & $\begin{array}{l}\text { na } \\
\text { na } \\
\text { na } \\
\text { na }\end{array}$ & $\begin{array}{l}\text { Negative } \\
\text { na } \\
\text { na } \\
\text { na }\end{array}$ & $\begin{array}{l}\text { na } \\
\text { na } \\
\text { na } \\
\text { na }\end{array}$ \\
\hline Lefkowitch et al (10) & $79 \mathrm{~F}$ & $\begin{array}{l}\text { Hodgkin's lymphoma mixed } \\
\text { cellularity }\end{array}$ & - & na & na & Positive \\
\hline Trewby et al (8) & $49 \mathrm{M}$ & Hodgkin's lymphoma & - & na & Negative & na \\
\hline Fairbank (9) & $\begin{array}{l}33 \mathrm{~F} \\
77 \mathrm{M} \\
52 \mathrm{M}\end{array}$ & $\begin{array}{l}\text { Hodgkin's sarcoma } \\
\text { Hodgkin's sarcoma } \\
\text { Hodgkin's granuloma }\end{array}$ & $\begin{array}{l}- \\
- \\
-\end{array}$ & $\begin{array}{l}\text { na } \\
\text { na } \\
\text { na }\end{array}$ & $\begin{array}{l}\text { na } \\
\text { na } \\
\text { na }\end{array}$ & $\begin{array}{l}\text { na } \\
\text { na } \\
\text { na }\end{array}$ \\
\hline
\end{tabular}

MMale: FFemale, na Not available 
The cells were mature T lymphocytes which expressed the T3 antigen and were of the T8 cytotoxic-suppressor subset.

Histologically, the authors designated this as malignant lymphoma, large cell immunoblastic and polymorphous in the working formulation (12). This subtype of high grade immunoblastic lymphoma was included in the formulation to encompass the wide spectrum of $T$ cell lymphoma reported in Japan and referred to as adult $T$ cell lymphomaleukemia (13). These neoplasms are endemic in southwestern Japan and are associated with a type $\mathrm{C}$ retrovirus, HTLV-1. The patients have lymphade-

ACKNOWLEDGEMENTS: The authors thank Dr Bruce Burns of the Ottawa Civic Hospital and Dr M. O'Shaughnessy of the Viral Surveillance Section at the Laboratory Centre for Disease Control, Ottawa, Ontario for their assistance with the antibody testing.

\section{REFERENCES}

1. Wright DH. Involvement of the liver by lymphoreticular disease. In: Wright R, Alberti KGMM, Karron S, MillwardSadler GH. eds, Liver and Biliary Disease. Philadelphia: WB Saunders Co, 1979:926.

2. Levitan R, Diamond HD, Craver LF. Jaundice in Hodgkin's disease. Am J Med 1961:30:99-111.

3. Kim H, Dorfman RF, Rosenberg SA. Pathology of malignant lymphomas in the liver: Application in staging. In: Popper H, Schaffner F, eds, Progress in Liver Disease V. New York: Grune and Stratton, 1976:683-98.

4. Carbone PP. Disease of the white blood nopathy with no mediastinal mass. They may have hepatosplenomegaly, skin involvement and osteolytic bone lesions with hypercalcemia. The median survival is less than one year. Histologically, the large majority of cases $(80 \%)$ are of medium sized cell type and pleomorphic type. In the latter, there are prominent giant cells, sometimes resembling ReedSternberg cells. Nuclear polymorphism is a striking feature of all subtypes. All Japanese cases are of the T4 helperinducer subset. However, adult $\mathrm{T}$ cell lymphoma-leukemia has been described in other racial groups $(14,15)$ and in nonendemic areas; some T8 phenotypes have been reported (15).

cells. Lymphoreticular neoplasms. In: Beeson PB, McDermott W, Wyngaarden JB, eds. Textbook of Medicine. Philadelphia: WB Saunders Co, 1979:1829-47.

5. Sherlock S. Acute (fulminant) hepatic failure. In: Sherlock S, ed. Diseases of the Liver and Biliary System, 6th edn. Oxford; Blackwell Scientific Publications, 1981:107-15.

6. Colby TV, LaBrecque DR. Lymphoreticular malignancy presenting as fulminant hepatic disease. Gastroenterology 1982:82:338-45.

7. Braude S, Grimson AES, Portman B, Williams R. Fulminant hepatic failure in non-Hodgkin's lymphoma. Postgrad Med J 1982;58:301-4.

8. Trewby PN, Portman B, Brinkley DM, Williams R. Liver disease as presenting manifestation of Hodgkin's disease. QJ Med 1979;189:137-50.

9. Fairbank WHD. Three atypical cases of Hodgkin's disease presenting with liver failure. Can Med Assoc J 1953;69:315-7.

10. Letkowitch JH, Falkow S, Whitlock RT. Hepatic Hodgkin's disease simulating
While the present case lacks many of the clinical features of the Japanese $T$ cell lymphoma-leukemia and is of the T8 phenotype, antibody testing for HTLV-1 was performed. Frozen serum was obtained post mortem to determine whether there were antibodies to HTLV-1; the test was negative.

In summary, lymphomas presenting acutely as fulminant hepatic failure are extremely rare. The authors believe this is the first such case in which cell surface markers were done and this shows a peripheral $\mathrm{T}$ cell lymphoma of T8 phenotype. This adds some further information to the spectrum of the $T$ cell malignancies.

cholestatic hepatitis with liver failure. Arch Pathol Lab Med 1985;109:424-6.

11. Zafrani ES, LeClercq B, Vernant J, Pinaudeau Y, Chomette G, Dhumeraux D. Massive blastic infiltration of the liver: A cause of fulminant hepatic failure. Hepatology 1983;3:428-32

12. The non-Hodgkin's lymphoma pathologic classification project. National Cancer Institute sponsored study of classifications of non-Hodgkin's lymphomas. Cancer 1982;49:2112-35.

13. Kadin ME, Berard CW, Nanba KN, Wakasa H. Lymphoproliferative diseases in Japan and western countries Proceedings of the United States-Japan seminar. Hum Pathol 1982;149:745-77.

14. Foucar K, Carroll TJ Jr, Tannous R, et al. Non-endemic adult T-cell leukemia/ lymphoma in the United States: Report of two cases and review of the literature. Am J Clin Pathol 1985;83:18-26.

15. Swerdlow SH, Habeshaw JA, Rohatiner AZS, Lister TA, Stansfeld AG. Caribbean T-cell lymphoma/leukemia. Cancer 1984;54:687-96. 


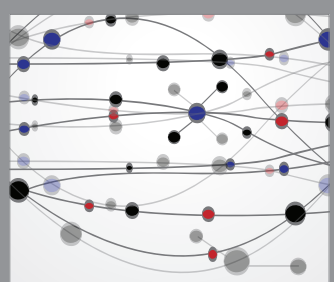

The Scientific World Journal
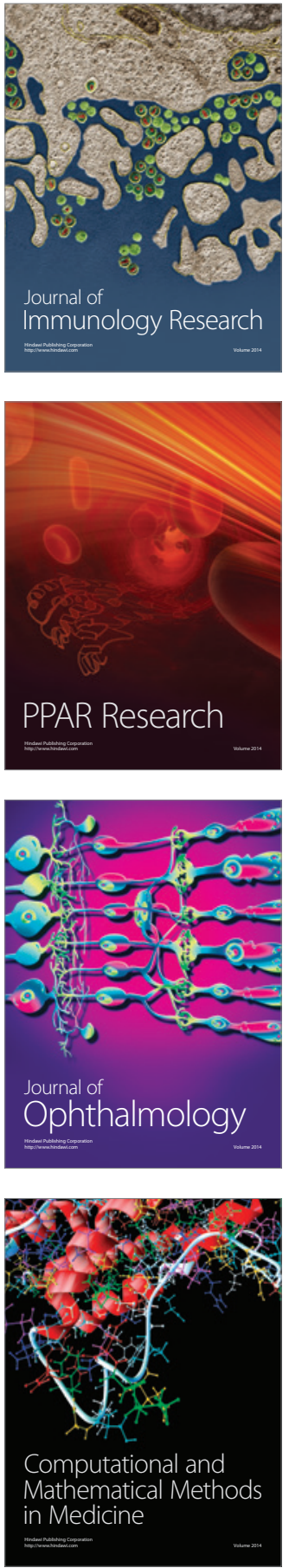

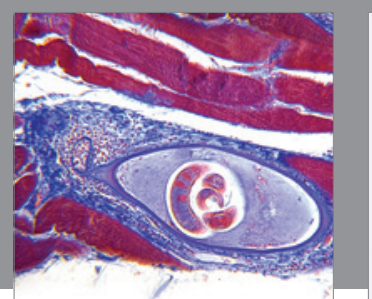

Gastroenterology Research and Practice

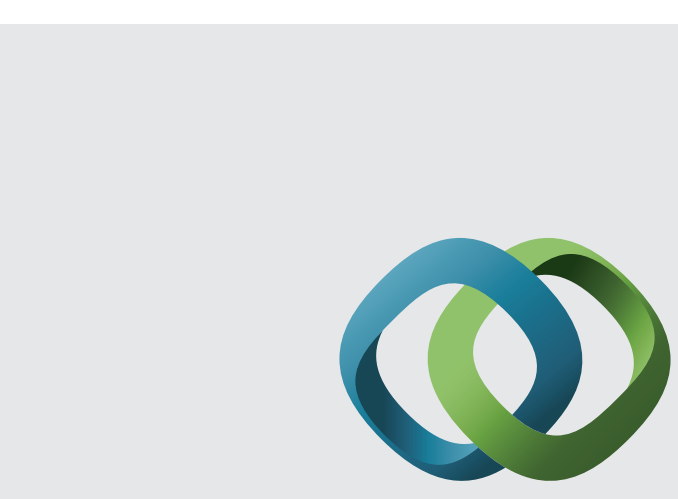

\section{Hindawi}

Submit your manuscripts at

http://www.hindawi.com
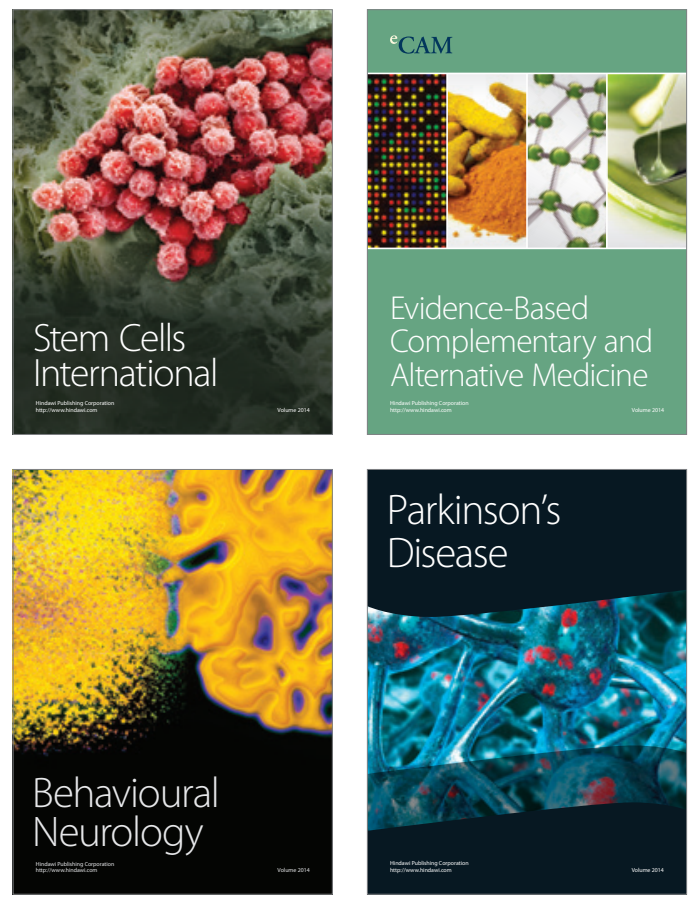
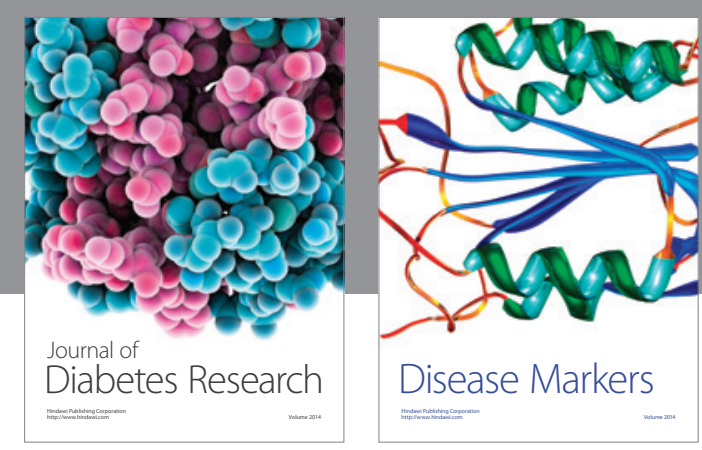

Disease Markers
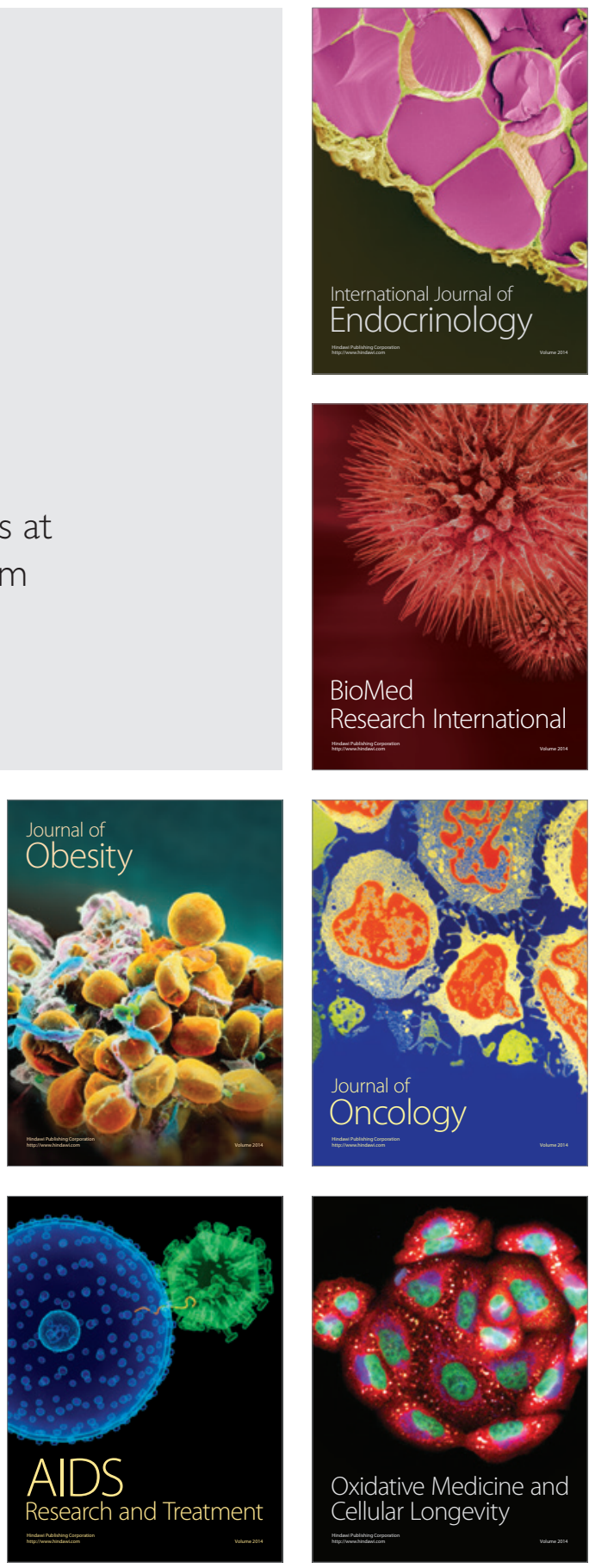